\title{
Integrating Indigenous Science with School Science for Enhanced Learning: A Nigerian Example
}

\author{
Stella Y. Erinosho \\ OlabisiOnabanjo University \\ Ago-Iwoye, Nigeria
}

\begin{abstract}
This study attempted to implement a teaching framework that was developed to place formal school science instruction in the context of indigenous scientific knowledgeand to assess its effectiveness on learning of concepts in science among secondary school students. There is increasing recognition of the importance of using indigenous (traditional) knowledge for contextualizing school science instruction because it forms part of students' prior experiences and source of information that they carry to school learning. Despite its proven effectiveness as useful teaching tool, there is yet no systematic effort to develop effective framework for incorporating indigenous knowledge into school science curricula to complement instruction process in $\mathrm{Ni}$ gerian schools. This case study involved eighty students in two Senior Secondary 111 science classes and six teachers. Students responded to an activity sheet and experience assessment questionnaire.The findings demonstrate the positive impact of the framework on cognitive learning among students. The teachers also gained insight into how the framework can be integrated into instructional procedure to support students learning. The implication for school science curriculum and instruction reform was highlighted.
\end{abstract}

\section{Introduction}

In Nigeria, as in many other African countries, the persistent dismal performance of students' and poor retention in science subjects continue to generate concern.Available evidence indicates that science learners generally do not sufficiently comprehend the knowledge and skills underlying the subjects, resulting in memorization, regurgitation and superficial learning of basic concepts and principles.Students often become bored in science classes complaining that the subject is difficult to understand and consistently asking: "What's the relevance of this" as they struggle to internalize learning material. Whereas some researchers have identified problem in the quality of learners, many others contend that the problematic is with theteaching of sci- ence thatis abstract and generallyout of touch with the reality of the world of learners, teacher-oriented, and lacking in creativity and relevance.Educators are thereforecanvassing for learner-centeredpedagogical approachesthat directly impact on cognitive and affective learning in science.

Although a number of theories that have been highly influential in understanding the process of learning have emerged, Vygotsky's [1] theory on social constructivism appears more relevant for the present study for his argument on the cultural basis of cognition. Vygotsky's pedagogical idea emphasizes the interplay of culture and social context in the construction of knowledge (learning) and understanding of events in the social setting of which the learning takes place. To social constructivists, meaningful learning is culture-bound and grows out of social encounters [2]. Seen in this sense, theknowledgethat a student acquires in school has an important connection with the learning acquired through everyday experience." The role of the social context is to scaffold the learner, and provide hints and help that foster co-construction of knowledge while interacting with other members of the society" [2]. Effective science learning is believed to take place in a situation that there is harmony in the cultural experience of the learner as determined by the school, the home and the community in which learning takes place. When there is such harmony, "science instruction will tend to support the pupils' view of the world, and the process of enculturation tends to occur" [2], whereby allowing for successful border crossing from the prior knowledge they hold from their cultural experiencesto the new experiences in school science. Effective border crossing has been shown to exert a significant positive effect on achievement in schoolwork and other cognitive activities $[2,3]$. The converse is also shown to affect school learning, that is, disharmony in the culture of science and pupil's life-world will make science instruction to cause disruption in the pupil's worldview through the process of what is referred to as assimilation which could lead to poor understanding of learning material.Hence, science educators have been shifting attention to pedagogical approaches and models that allow for 
context bound science engagement in the learning processes.Underpinning this pedagogical idea is the understanding that supporting learners to build their knowledge base within a conceptual domain that draws upon their social background experiences and cultural worldviews can reinforce learning. Also, presenting teaching material to enable learners build on existing cognitive schema increases students' ability to grasp learning material [5]. In addition, research evidence shows that when students find personal relevance supported by concrete experience in the material they are learning, they learn better and are more apt to retain information $[5,6]$.

Contextualization is an important pedagogical approach for extending school science outside of the classroom to connect with existing knowledge in the immediate locality, which is considered as learner's prior experience. Prior knowledge makes up a student's experiential knowledge that serves as a foundation to build on and learn new concepts.Indigenous scientific knowledge offers a useful tool for contextualizing school science instruction. Indigenousscience is referred to as science at the culture or society level $[7,8]$ and described as"thestudy of systems of knowledge developed by a given culture to classify the objects, activities, and events of its given universe" [9]. Knowledge of indigenous science has been viewed to provide a pedagogical stepping stone, especially for multicultural students of science [10] and experiential schemaon which to build school science concepts and principles [6]. This is mostlybecause it forms part of students' priorexperiencesandsource of information that they carry to school learning.

Until recently the pedagogical importance of indigenous science was dismissed by the advocates of the universality and infallibility of Western or formal science who had held contrary viewsregarding the workability of integration with indigenous science [11], or relevance of indigenous science in classroom instruction [12] because traditional knowledge or indigenous science is perceived as non-quantitative and unscientific.However, researchers in Africa(and some other societies inhabited by indigenous people) areincreasingly accordingrecognition to indigenous (traditional) knowledge for its value to complement formal scientific understanding $[13,14,15,16]$.As a pedagogical tool, it is believed to give "added depth and meaning to difficult concepts, and builds communication and respect with the community" and "also helps to make science less foreign to students" [17]. In addition, bringing students in contact with the indigenous people in the process of schooling will help them to respect their cultural values and to clarify the misconception about indigenous knowledge as lacking value, unscientific, bereft of useful knowledge and outside the realm of 'real' science. Inclusion of indigenous knowledge in science curriculumcould provide a starting point for "reconciliation of traditional knowledge with science" and for embracing a people-oriented development of societies [14, $15,18]$.

Two examples that have successfully implemented an inclusive curriculum are the Popular Participation in Curriculum and Instruction (PoPCI) implemented in Ethiopia and the Alaska Rural Systemic Initiative project (AKRSI). The PoPCIfocuses on integrating the indigenous knowledge (IK) of a local community in Ethiopia into the formal school curriculum by teamingup classroom teachers with "local experts" to create and deliver lessons for primary school students on relevant topics such as carpentry, pottery, blacksmithing, weaving and agriculture. The project was found useful in the sense of allowing students to value their community knowledge as equivalent to what is taught in school. Students also began to value local and modern sector occupation choices after their graduation.Also, the AKRSI example follows a similar template as PoPCI by incorporating Native Alaskans' knowledge and culture into the conventional school curriculum. As an example, in science classes, students learn about physical concepts of tension, force, and weight by studying the snowshoes that Native Alaskans wear. These projects demonstrated how students unfamiliar with content taught through the conventional curriculum were made to learn to appreciate it when connections are made to the knowledge they hold from their environment and communities [5].

Despite its proven effectiveness as useful pedagogical tool and a good starting point for engaging students in development issues [18] there is yet no systematic effort to develop effective framework for incorporating indigenous science into school science curricula and instruction process in Nigerian schools. Nigeria is multi-cultured society with rich repertoire of indigenous activities and ways of knowing that carry expressions of scientific thinking in their application, such as in food production and preservation, metal production, textile processing, building and farming techniques. The knowledge resource from these activities, though available for teachers as pedagogical tool for facilitating science instruction processes and providing real experiences for learners, is yet to be given recognition in science curricula. Nonetheless, the bold step of some African countries is recognised in this regard (e.g., Zimbabwe, Tanzania, South Africa) even though still not widely accepted.

The purpose of this case study therefore was toimplement a teaching framework that places formal school science instruction in the context of indigenous scientific knowledge for supporting learning of concepts and stimulating interest in science among secondary school students. Specifically, the objectives were to extend the boundary of school science to the local 
community using examples of indigenous science to reinforce the teaching of school science concepts and to assess the impact on cognitive learning and interest in science.

\section{Method}

\subsection{Sample}

The study involved eighty high school science students ( 45 boys and 35 girls) in final year of Senior Secondary (SS3 classes) and six science teachers (two each for physics, chemistry and biology). Four indigenous activities drawn from three major areas (namely, food, textile, and metal production) were focused upon as examples for the case study.

\subsection{Instruments}

Two major instruments were used: 1) Student activity sheets tagged "Science in Action in Community (SAC)". These were drawn to assess the students' knowledge of the scientific ideas underlying each of the four indigenous activities. $S A C$ is a test measuring students understanding of': (a) the production steps in each indigenous activity; (b) the underlying scientific explanation of the actions; (c) identification of related school science concepts; and (d) explanation of the concepts. For each indigenous activity, students responded to the following items under A \& B:

e.g. Metal production (blacksmithing)

\section{A. To measure awareness}

- I know where it is produced in town Yes No

- I can explain the production process

- I had visited the site where it is produced

- I had asked about the production procedure

- I would like to visit the place where it is produced

\section{B. To measure knowledge}

1. List the activities that are involved in making a cutlass

2. Identify the concepts that you have learnt in science that are being used in the production process

3. Explain the concepts that you have identified.

Students' responses on the measure of knowledge were scored against the framework prepared for the activity (see Table 1).

The scoring points are given as follows:

- Cannot provide an answer

○ Provide $50 \%$ of the required answer
- Provide $75 \%$ of the required answer

- Provide all the required answer

2) Experience Assessment Questionnaire. This is a short questionnaire consisting four items measuring the impact of the visit on students. The items are:

Considering your experience at the site visited, tell us about:

a. Your impression of the local activity

b. How you think that studying science canaffect your society

c. Your understanding of the concepts compared to when you were first taught in class

d. Your opinion on whatthis visit meant to your learning of science in school

\subsection{Procedure}

First, a resource manual was developed by a team of science educators covering eleven examples of indigenous activities and showing the links between concepts and principles in school science and indigenous procedure. A short note follows each activity explaining the concepts therein and raising learning tasks for students.Four indigenous technologies were selected as case study. The relevant sections of the manual were made available to each teacher to serve as guide. Before exposure to each indigenous activity, SCA sheet was administered to the students. Then, the students were taken in four groups to visit the indigenous activity sites and interact with the local artisans and their activities. At the site, the local artisan took the students through the processes involved in the activity, and was encouraged to give the reasoning for each of the steps being taken. Then the researcher together with the science teachers used the local reasoningprovided by the artisans to give scientific explanations underlying the activities. The relevant school science concepts were identified, which the teacher further explained by linking to the indigenous activity. Students' were made to also try their hands on the activity or use some of the local gadgets. For example, at the cassava processing site, students tried to establish the changes in ph at each stage of fermentation. They also tried using the spinning gadget at the cloth weaving site, changing the tension and observing the effect on the speed. After each study visit, students also responded to the short questionnaire to assess the impact of the visit, in addition to SAC.

\section{Results}

A significant observation was the excitement shown by the students to be at these sites, located in the indigenous part of towns where a number of them probably 
would not venture visiting. Interacting with the local artisans to them was fun, while the artisans also were visibly excited that their activity was being recognized for teaching students.One of them commented...do you mean that you find our work useful ... encouraged that you come down to our level...were relegated to low level... my children also not interested in the work, only for old people (translated).

\subsection{Measure of awareness and interest}

The initial survey to identify students' awareness and knowledge of the indigenous processes clearly demonstrated students' disconnection with the activities. Only about $10 \%$ of students were familiar with all the four activities, about $35 \%$ had interacted with at least one of the activities, while only about $14 \%$ had asked for information about the production procedure. None of them could identify at least two operational steps that had scientific bearing. Figure 1 shows the details of students' responses for each activity.

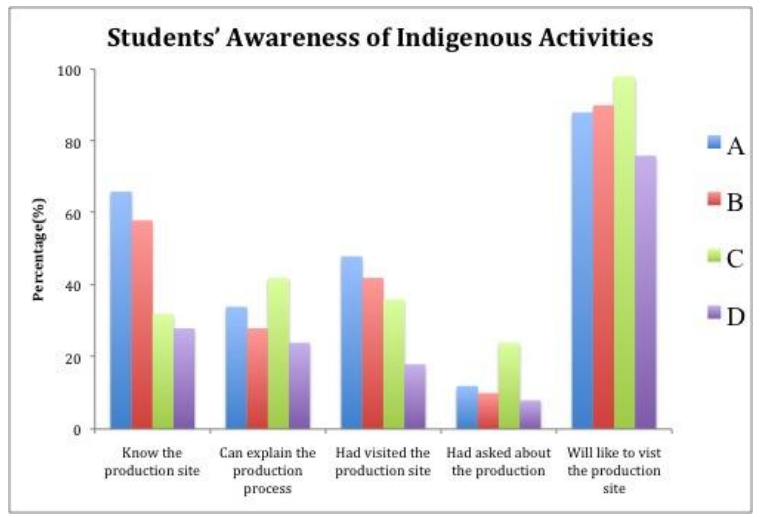

Figure 1. Measure of Students' awareness of Indigenous activities and interest

Note: $\mathrm{A}=$ fufu, $\mathrm{B}=$ gari, $\mathrm{C}=$ asooke, $\mathrm{D}=$ blacksmithery

What's more, the teachers were also found not to have a good grasp of the scientific knowledge underlying these activities, and were also not too confident with their application in school science.

The visit made positive impact on the students'perception of indigenous activities. Below are interesting excerpts that underscore their experience and perception:

- Cannot believe that it takes so much pain to process cassava to ...

○ Eat fufu for the first time. I pity the women making it...Wish their work can be made easier, especially the conditions under which they work.

- Fermentation produced acidic medium... litmus paper changed colour in the water that was used to soak cassava.
- Always see them using weights to press cassava.. had never linked it to pressure.

- Need to improve the process of drying cassava grains. I mean the smoke was too much for the women... not healthy for them.

- I agree with you that science is around us, but we need to see more examples

- Can you imagine that they made practical use of levers, circular motion, without knowing it? Good illustration of the concepts.

- Good outing... opportunity to see science in everyday activities.

- Wish science lessons can be made as interesting always...

- I believe that we can come together to think on what to do to improve the efficiency of the lever used by the blacksmith...they have tried.

- We use cutlass often, but cannot imagine how it is made... would not have believed it is science.

\subsection{Assessment of cognitive gain}

The cognitive gain was measured at four levels: identification of production steps, scientific explanation for the steps identified, identification of scienceconcepts, and explanation of the concepts that underlie the four activities by comparing students' pretest and post-test scores on the "SAC Test". Table 1 shows the pre- and post-test mean scores (M) and standard deviation (SD) of students' performance on the cognitive knowledge for the four activities. The difference between mean scores (D) is highest for identification of steps (3.68), followed by explanation of concepts (3.57) and least for identification of concepts (3.48).

Table 1. Mean scores on SAC

\begin{tabular}{|c|c|c|c|c|}
\hline Action & $\begin{array}{l}\text { Befo } \\
\text { Afte } \\
\text { M }\end{array}$ & $\begin{array}{lll}\mathrm{e} & & \\
\mathrm{SD} \quad \mathrm{M} \quad \mathrm{SD}\end{array}$ & $\mathrm{D}$ & $\mathrm{p}$ \\
\hline Identify steps & 3.94 & $\begin{array}{lll}1.14 & 7.62 & 2.38\end{array}$ & 3.68 & .00 \\
\hline $\begin{array}{l}\text { Provide scien- } \\
\text { tific reasoning }\end{array}$ & 3.65 & $\begin{array}{lll}8.39 & 7.14 & 1.68\end{array}$ & 3.49 & .00 \\
\hline $\begin{array}{l}\text { Identify con- } \\
\text { cept }\end{array}$ & 4.58 & $\begin{array}{lll}1.02 & 8.06 & 1.73\end{array}$ & 3.48 & .09 \\
\hline $\begin{array}{l}\text { Explain con- } \\
\text { cepts }\end{array}$ & 5.34 & $\begin{array}{ll}1.188 .91 & 0.19\end{array}$ & 3.59 & .01 \\
\hline
\end{tabular}

The t-test comparison showed higher cognitive gain after exposure to the activities $(\mathrm{p}<.05)$. Students were 
more able to identify $(\mathrm{M}=8.06)$ and explain the science concepts $(\mathrm{M}=8.81)$ after exposure to the activities.

\subsection{Teachers' opinion of the instructional Framework}

Even though the teachers recognized the instructional merit of, and the useful insight provided into the scientific undertones of the various activities, they however expressed reservation about its adoption in the teaching process. The comments though not unexpected are worth documenting for the purposed of future reform:

1. Logistic problems: Having to take the students out of school would incur costs, disrupt the school timetable, not as straightforward to manage given that they would have to teach other classes, slow down coverage of course content.

2. Usefulness: The students are passing their examinations without going through this extra trouble, so of what use?

3. Coverage of course content: Given the limited time to prepare students for the final exams, how would they cope?

4. Use as excursion: Its better used as excursion just to get students familiarize with the activities.

\section{Conclusion}

The findings of the study has demonstrated that teaching methods which incorporate indigenous scientific knowledge as the tool for providing experiential bases for formal science learning can be beneficial for reinforcing learning. Students showed increased understanding of the scientific concepts and demonstrated visible excitement in their interaction with the local resources.Also, the teachers who initially were found to lack deep understanding ofthe connection gained insight into the underlying processes and how their lessons could benefit from incorporating the examples. The literature also recognizes the beneficial effect of the learner's socio-cultural background in the teaching and learning of science for a strong foundation and effective learning outcomes [11].

The benefit of contextualizing school science within indigenous scientific knowledge might be in the dynamics of the instructional environment that is more open, flexible, and interactive. Teaching science with such resources helped thestudents to see the relevance and applicability of the subject content.For instance, the local cloth weaving (asooke) provided practical resource to simplifythe concepts of tension, gravitational force, andcircular motion. Students also had a chance to see inaction practical use of lever system, incompleteburning, flames and tensile strength at the blacksmith site.This experience is incomparable to learning byparroting and regurgitation that exist in the typicalconventional science classes. The excitement along with the fact that students experienced increased understanding of the conceptscould provide the ingredients to developinterest to learn science.

Not only does the use of indigenous scienceprovide platform for contextualizing teaching, it alsogives opportunity for students to learn about the activitiesin their community that were discountenancedand which knowledge is dying out due tolack of engagement of younger generation. The learner's social interaction with the practitioners in the local context enables them to acquire meaning of important science related processes and learn how to use them. At the same time, giving students the exposure to local contextshas the potential advantage of stimulating theiringenuity for the improvement of their society assome of the students in the study even interrogatedthe work conditions of the local experts.

To be used as a pedagogical tool, the teacher would need to have prior knowledge and understanding of the processes involved in the various activities in the community and their appropriate application to school science. Snively [19] suggests useful instructional hints to teachers to provide a "multicultural view" of science and technology by drawing upon a variety of cultures when teaching science and to adopt teaching strategies that emphasize solving sustainable societies' problems".There is science in the farm, the mechanic shop, the hospital, construction sites etc., which have prospects of helping students who have difficulty comprehending the principles and concepts being taught directly to attach meaning to them. Teachers need to be supported to use these resources in order for them to embrace the principle of contextualization of school science. Ogunniyi et al. [20] suggest a conceptual ecocultural frameworkthat should help pupils negotiate their cultural borders into school science to consist of the following features:

1. Generating information about the pupil's everyday environment to explain natural phenomena.

2. Identifying and using the Indigenous scientific and technological principles, theories, and concepts within the pupil's community.

3. Teaching the typical values of the Indigenous community in relation to, and in the practice of, science and technology as human enterprises.

No doubt, teachers in many African countries operate a restricting examination-bound syllabus, which tend to make them less responsive to innovative instructional methods. For example, an attempt to implement such inclusive curriculum in Zimbabwe found that "the 
teachers totally dismissed incorporating indigenous science in school programs. ...those who equated school science with Western science were cynical about indigenous knowledge...Western science was accorded a higher status than indigenous knowledge" [17].The implication therefore, is that it is not enough to have a reform of science curriculumto make it culturally sensitive by the use of examples in the community, rather, it must also have in-built methodological framework that will support teachers in the classroom.

Table 2.Blacksmithing: Metal products

\begin{tabular}{|c|c|c|c|}
\hline Procedure & Local reason & $\begin{array}{l}\text { Scientific } \\
\text { explanation }\end{array}$ & $\begin{array}{l}\text { Science } \\
\text { Concepts }\end{array}$ \\
\hline $\begin{array}{lr}\text { Fire } & \text { kernel } \\
\text { shells in } \\
\text { clay fur- } \\
\text { nace }\end{array}$ & $\begin{array}{l}\text { Kernel shells } \\
\text { burn slowly } \\
\text { and produce } \\
\text { high heat; Clay } \\
\text { furnace keeps } \\
\text { longer }\end{array}$ & $\begin{array}{l}\text { Action of } \\
\text { organic ma- } \\
\text { terials with } \\
\text { oxygen; }\end{array}$ & $\begin{array}{l}\text { Oxidation; } \\
\text { burning; } \\
\text { Exothermic } \\
\text { reactions; } \\
\text { Heat of } \\
\text { combustion; } \\
\text { Calorific val- } \\
\text { ues }\end{array}$ \\
\hline $\begin{array}{l}\text { Stoke fire } \\
\text { in the fur- } \\
\text { nace } \\
\text { through } \\
\text { bellows. }\end{array}$ & $\begin{array}{l}\text { Bellows help to } \\
\text { collect air and } \\
\text { keep fire burn- } \\
\text { ing }\end{array}$ & $\begin{array}{ll}\text { Action } & \text { of } \\
\text { oxygen } & \text { in } \\
\text { burning; } & \end{array}$ & $\begin{array}{l}\text { Air and } \\
\text { combustion; } \\
\text { Lever system }\end{array}$ \\
\hline $\begin{array}{l}\text { Insert one } \\
\text { end of long } \\
\text { metal scrap } \\
\text { in middle } \\
\text { part of } \\
\text { flame until } \\
\text { red hot }\end{array}$ & $\begin{array}{l}\text { Long metal } \\
\text { does not get } \\
\text { hot at the other } \\
\text { end; Heat sof- } \\
\text { ten the metal; } \\
\text { middle part of } \\
\text { fire hotter. } \\
\text { Heat flow slow } \\
\text { down the long- } \\
\text { er the metal; }\end{array}$ & $\begin{array}{l}\text { Electronic } \\
\text { (or ionic) } \\
\text { changes in } \\
\text { metals }\end{array}$ & $\begin{array}{l}\text { Conduction; } \\
\text { Physical } \\
\text { property of } \\
\text { ferrous metals; } \\
\text { flame }\end{array}$ \\
\hline $\begin{array}{l}\text { Compres- } \\
\text { sion of hot } \\
\text { metal to } \\
\text { required } \\
\text { shape, and } \\
\text { filing of } \\
\text { blunt end }\end{array}$ & $\begin{array}{l}\text { Heat softens } \\
\text { metal; filing is } \\
\text { for thinning out } \\
\text { the end to } \\
\text { make it sharp }\end{array}$ & $\begin{array}{l}\text { Heat breaks } \\
\text { down metal- } \\
\text { lic bonding; } \\
\text { Filing re- } \\
\text { duce the } \\
\text { pressure area }\end{array}$ & $\begin{array}{l}\text { Tensile } \\
\text { strength; appli- } \\
\text { cation of thrust }\end{array}$ \\
\hline
\end{tabular}

\section{References}

[1] G. H. Wheatley, "Constructivist perspectives on science and mathematics learning, Science Education, 75(1), 1999, pp. 9-21.

[2] O. J. Jegede, G. Aikenhead, "Transcending cultural borders: Implications for science teaching. Research In Science And Technology Education, 17 (1), 1999, pp. pp. 45-66.

[3] O. J. Jegedeand, P. A. Okebukola, "The effect of instruction on socio-cultural beliefs hindering the learning of science.Journal of Research in Science Education, 28, 1991, pp. 275-285.
[4] N. Cossons, "Let us take science into our culture. Interdisciplinary Science Reviews, 18(4), 1993, pp.337-342.

[5] IK Notes "Education: Building on indigenous Knowledge" No. 87 December 2005.

[6] M. Michie, "Why indigenous science should be included in the school science curriculum, Journal of Cognition and Culture, 4 (3-4), 2002, pp. 409-450.

[7] L. C. Sommer, C. E. Talus, M. Bachman, and F. Barnes, "The importance of traditional knowledge in science education: ARM Education uses interactive Kiosks as Outreach Tool", Fourteenth ARM Science Team Meeting Proceedings, Albuquerque, New Mexico, 2004, pp. 22-26

[8] M. Ogawa, "Science education in a multi-science perspective. Science Education, 79, 1995, pp. 583-593.

[9] D. L. Hardesty, Ecological anthropology. New York: Wiley, 1977.

[10] M. Atwater, J. Riley, "Multicultural science education: Perspectives, definitions, and research agenda. Science Education, 77, 1993, pp. 661-668.

[11] W.W. Cobern, C. Loving, "Defining science in a multicultural World:Implications for science teaching. Science Education, 85 (1), 2001, pp. 50-67.

[12] H.A. Brown-Acquaye, "Each is necessary and none is redundant: The need for science in developing countries", Science Education, 85 (1), 2001, pp.68-70.

[13] S. Mackinson "Integrating local and scientific knowledge: An example in fisheries science. Environmental Management 27, 2001, pp. 533-545.

[14] Keins Phiri, "Exploring the integration of indigenous science in the primary school science curriculum in Malawi", Dissertation submitted to the faculty of the Virginia Polytechnic Institute and State University, 2008.

[15] G. Boyne, "Utilizing traditional knowledge in a scientific setting".Wind of change: A magazine for American Indians in Science and Technology, 48 (1), 2003, pp. pp.52-54.

[16] E. Shizha, "Critical analysis of problems encountered in incorporating indigenous knowledge in science teaching by primary school teachers in Zimbabwe. The Alberta Journal of Educational Research Vol. 53(3), Fall 2007, pp 302-319.

[17] S. Kroma, "Popularising science education in developing countries through indigenous knowledge", Indigenous Knowledge and Development Monitor, 3(3). Dec. 1995, pp. 15 .

[18] G. Snively and J. Corsiglia, "Discovering indigenous science: Implications for science education. Science Education 85: pp.6-34. 
International Journal for Cross-Disciplinary Subjects in Education (IJCDSE), Volume 4, Issue 2, June 2013

[19] M. B. Ogunniyi, O.Jegede, M. Ogawa, C.D. Yandila, and F. K. Oladele, "Nature of worldview presuppositions among science teachers in Botswanna, Indonesia, Japan, Nigeria, and the Philippines. Journal of Research in Science Teaching, 32, 1995 , pp. 817-831. 